\title{
RETHINKING THE BLACK SEA: BETWEEN THE TRANS-ATLANTIC AND THE EURASIAN PROJECTS
}

\author{
Şerban Filip Cioculescu, PhD \\ University of Bucharest, Department of Political Science
}

\begin{abstract}
The Black Sea region as a buffer between great powers and cordon sanitaire was and still is important in European history. After the $18^{\text {th }}$ century, the Russian empire began a gradual but unstoppable move towards the conquest of the region, leading to a setback for Turkish influence. The Crimean War enabled Western powers to contain Russian expansion for some decades. For small and medium-sized countries like Romania, it is difficult to erase historic experiences from their collective memory. During the Cold War, the Black Sea was a virtual "Soviet lake" from a military point of view. The West controlled only the straits "owned" by Turkey following the Montreux Convention. After the implosion of the USSR, this strategic area was neglected by the Western powers and viewed by the Russian Federation as a traditional sphere of influence. Since 1991, Ukraine holds about $30 \%$ of the northern shore of the Black Sea, Georgia controls roughly $12 \%$ of the maritime littoral (including the separatist territories) while Russia owns about $13 \%$ of the Black Sea shores. Turkey and Ukraine hold the biggest share of the Black Sea shore. Generally speaking, during the two last decades, there have been two competing visions about the future: the Euro-Atlantic one, which insists on opening and internationalising the sea, and the Eurasian vision, which wants the Black Sea to remain closed and impenetrable to foreign interferences. This article deals with these issues.
\end{abstract}

\section{Introduction}

Since the time of the ancient Greek city-states, the Roman Empire, then the

Scientia Militaria, South African Journal of Military Studies, Vol 41, Nr 1, 2013, pp. 1-33 doi : $10.5787 / 41-1-1051$
Byzantine Empire and the Ottoman Empire, the geographic region of the Black Sea has been important in European history. It has always being a kind of "imperial line", a buffer area between great powers, a cordon 
sanitaire against barbarian invasions and, of course, an area of economic routes linking Western Europe with the Middle East, India and the Far East. After the $18^{\text {th }}$ century, the Russian Empire began a slow but unstoppable march towards the conquest of the region, leading to a setback for Turkish power. The Crimean War (1853-1856) allowed Western powers especially France and Great Britain to contain the Russian expansion for some decades, but it was only during World War I that Russian geopolitical expansion and the dream to take the straits and force an access to the Mediterranean Sea was stopped. For small and medium-sized countries like Romania, it is difficult to erase some traumatic historic experiences suggesting Russia's open advance towards hegemony in the Black Sea, like the secret AngloFrench convention of 1915, from their collective memory. The same applies to Stalin's USSR heavy pressure on Turkey to allow Moscow to install military bases in the straits in $1945 .^{1}$

During the Cold War, one could virtually describe the Black Sea as a "Soviet lake" from a military point of view, as the Western camp controlled only the straits "owned" by Turkey following the Montreux Convention according to the regime of the straits as from $1936 .^{2}$ For a decade after the end of the bipolar rivalry and the breaking up of USSR, the area had been largely neglected by the Western powers and targeted by the Russian Federation as "natural" sphere of influence, according to the doctrine of the near abroad. The Montreux Convention could be seen as an attempt to close the Black Sea to foreign powers and to recognise Turkey's role of "watchman", while the previous legal document, the Lausanne Treaty of 1923, granted the Black Sea the status of an open sea.

After 1991, the year of USSR's collapse, the new geographic map of the Black Sea coasts offered a new framework: Ukraine now holds about $30 \%$ of the northern area, including the strategically important Crimean Peninsula, Georgia has about $12 \%$ of the maritime littoral, while Russia, the main inheritor of the Soviet Union, owns only about $13 \%$ of the Black Sea shores. Of course, Turkey and Ukraine hold the biggest shares of the Black Sea, but Ankara has the additional great strategic advantage of controlling the Bosporus and Dardanelles Straits.

Currently, one could identify in this area two competing visions regarding its future: the Euro-Atlantic vision, which insists on opening and internationalising the area and the Eurasian vision, which wants the Black Sea to remain closed and impenetrable for foreign interferences. As an example, some of the NATO members (Romania, Bulgaria, Poland, USA before 2009) want an open sea, while Russia and Turkey prefer to keep it close. 


\section{NATO and EU's Presence: the Western Vision}

The North Atlantic Treaty Organisation (NATO) is certainly present in the Wider Black Sea Area, its security complex encompassing the riparian states (Bulgaria, Georgia, Romania, Russian Federation, Ukraine and Turkey) but also Azerbaijan, Armenia and the Republic of Moldova. ${ }^{3}$ Bulgaria, Romania and Turkey are NATO members; the other countries are partners of this Western security organisation. However, could one still speak of a single "West" or is there a somewhat multiple geometry framework coming to the fore?

After the end of the Cold War, NATO had been present in the Black Sea region through the implementation of a huge security framework based on developing cooperative ties and enhancing mutual trust among the former enemies of the Cold War: ex-communist states and Western democratic states. The most important tools that the allies proposed to their eastern neighbours were Partnership for Peace (PfP) Intensified Dialogue, MAP (Membership Action Plan), IPAP (Individual Partnership Action Plan), Partnership Action Plan on Defence Institution Building (PAP-DIB) and Partnership Action Plan against Terrorism (PAP-T).

The main framework for the new cooperation era has obviously been the Partnership for Peace agreement, which was signed in 1994 to support the internal reform of the defence sector in partner countries, thus covering areas like the defence budget, the civilian control on armed forces, enhancing the interoperability, defence legislation, defence planning and joint military exercises. To meet the objectives of reform, the PfP has developed a number of instruments such as the Individual Partnership Programme (IPP), ${ }^{4}$ the Partnership for Peace Planning and Review Process (PARP), Operational Capabilities Concept (OCC), the politicomilitary framework for PfP operations, the PfP Trust Fund, and the partnerships for action.

Another important instrument for cooperation among partners is the intensified dialogue with NATO. This was first referred to at the NATO summit in Madrid in 1997, namely a framework of cooperation with those nations that aspire to become NATO members, but without guaranteeing membership. Currently, in terms of remnant states, NATO opened its intensified dialogue with Ukraine in 2005 and with Georgia in 2006. While Georgia is still considered as a potential NATO state, included in the Chicago Summit statement of 20 May 2012, ${ }^{5}$ Ukraine withdrew its application after deciding that neutrality was the best option for its national security. However, the Ukraine remains a cooperation partner for NATO.

The instrument, which has "restructured" NATO's relations with candidate states, is the Membership Action Plan (MAP), which was launched at the NATO 
summit in Washington in 1999 as a practical manifestation of the "open door". MAP is divided into five chapters aimed at political and economic issues, defence and military security, defence resources and legislation, under which each state aspiring to become a NATO member draws up a national action plan.

As NATO states needed an effective instrument for promoting military compatibility between themselves and the armed forces of their partners, they launched the Individual Partnership Action Plan (IPAP) at the NATO summit in Prague in 2002. This allowed the adequate framework for cooperation, focusing on the defence priorities and the requirements of security sector reform, in accordance with the needs of each partner state. It is important to note that participation in the IPAP is based on the partner's individual choice and does not guarantee at all its accession to NATO. IPAP cycles are conceived for a period of two years, and are based on tools developed in the Partnership for Peace Planning and Review Process (PARP). Objectives envisaged in the IPAP cover a wide range of political issues (such as relations with neighbours, fighting corruption, strengthening the rule of law, etc.), security, defence, public information, civil emergency planning in the field and other measures. Enhanced political dialogue can be part of IPAP. The Black Sea countries endorsed IPAP: Georgia (October 2004), Azerbaijan (May 2005), Armenia (December 2005), Moldova (May 2006), Kazakhstan (January 2006). NATO tries to support the partners' domestic security and defence reform efforts. Individual Partnership Action Plans (IPAPs) are open to countries that manifest the political will and capacity to enhance relationships with NATO. In fact, this suggests only a technical progress, by improving defence-related issues and security sector reform in accordance with NATO standards; however, there is also a tacit assumption that the partner countries will gradually adopt some of the allied values like democracy, human rights and the rule of law.

PARP's first cycle was launched in December 1994 by NATO members and 15 partners, as the 1994 PfP Framework Document committed the Alliance to develop with the partner countries a so-called "planning and review process", in order to assess the pool of forces and capabilities which could be made available for multinational joint training, common exercises and other operations carried up with the allied forces. In 1997, there was a decision that PfP operations be extended beyond peacekeeping, search and rescue and humanitarian operations, to cover all the existing new missions of NATO, like peace support operations. PARP implies two-year planning cycles and is based on the Survey of overall PfP interoperability, a document issued by NATO at the end of the second year, followed by the partners voluntarily providing information on the security policy including their defence policies, the democratic control of the armed forces, PfP cooperation for each of them and financial issues of the whole process. NATO thus regularly issues a 
planning and review assessment and delivers the partnership goals to support each partner in its efforts to make its armed forces more compatible with the allied forces. All these agreements and force commitments are to be found in the Consolidated Report, a document jointly agreed by the allies and their partners. ${ }^{6}$

NATO organised military exercises under the PfP framework in bordering countries such as Georgia and Ukraine, and tried to extend Operation Active Endeavor from the Mediterranean into the Black Sea but met Turkey's resistance in addition to Russia's disapproval. Ankara and Moscow seemed willing to create a shared sphere of influence over the Black Sea. Meanwhile NATO had established relations with all countries in the Black Sea under the aegis of PfP, including the neutral Republic of Moldova. In addition to the older NATO-Ukraine Commission (1997), the new NATO-Georgia Commission was created in the autumn of 2008 after the Georgian-Russian war, as a tool to enhance Tbilisi's relations with the Western alliance. At the North Atlantic Council summit in April 2008 in Bucharest, both countries had been promised that they would officially join the organisation but without receiving the Membership Action Plan and a concrete date for membership. Unfortunately, the war with Russia made Georgia's accession perspectives very remote (because some NATO members would invoke the existence of conflicts with the neighbours and the Russian opposition to enlargement, while good neighbourhood is a precondition for membership). At the same time, the result of presidential elections in Ukraine brought to power a much more cautious politician, not as Western-oriented as the previous president.

Frequently, the desire of the NATO members to involve the local states' armed forces in joint exercises generated hostility or at least suspicion. Thus, the Sea Breeze 2008 joint military exercise to be organised by NATO and Ukraine in the Black Sea was cancelled because of the pro-Russians' street protests in the Crimea. ${ }^{7}$ The Eastern Ukraine was heavily dominated by Russophones who were instrumental in Moscow's plans to stop NATO's further enlargement to the East. At the end of 2008, several representatives of the Regional Council of Crimea were sent to the national Supreme Rada (parliament) calling for cancellation of NATO exercises, which, in their view, would jeopardise the territorial integrity and sovereignty of Ukraine. In the summer of 2009, Exercise Sea Breeze was not executed at all. Some month before, the Supreme Rada (the Ukrainian parliament), had rejected the presidential draft law allowing foreign forces to come to Ukraine for participating in joint military exercises. Anti-NATO sentiments, carefully cultivated by pro-Russian elements, which constituted a serious obstacle to this country's joining the Alliance at least between 2004 and 2009. Under the presidency of Viktor Yanukovych, Ukraine withdrew its candidacy for NATO membership, proclaiming a "no-bloc policy", which meant neutrality. One could say that eventually Kyiv (or Kiev, the 
capital and the largest city of Ukraine) could not then and seemingly now also, escape the logic of regional disputes and tensions from within and outside the region. The Crimea was and still is, a contentious issue between Russia and Ukraine. In 1954, the USSR government transferred the Crimea Region from the Russian part of the Union of Soviet Socialist Republics to the Ukrainian Soviet Socialist Republic. Then, after 1991, the Russian Federation acknowledged the status quo. Still, when former Ukrainian president Yuschenko openly supported the country's main regional ally, Georgia, in its war efforts against Russia in the summer of 2008, some top Russian politicians mentioned the scenario of the Crimea going back to Russia. $^{8}$

NATO and EU expansion to Eastern Europe have led to changes in the pattern of major geopolitical units such as the Wider Black Sea Area (WBSA) and in general, also in Eastern Europe. ${ }^{9}$ Russia has frequently shown contradictory attitudes. On the one hand, it joined the Partnership for Peace in 1994 and agreed on a "joint council" with NATO. On the other hand, Moscow intensified efforts to integrate former Soviet republics in the Collective Security Treaty Organisation (CSTO), fearing Western geopolitical penetration in the traditional Russian area of influence. In the present and the foreseeable future, the Russian Federation clearly remains the main factor of power within the Commonwealth of Independent States (CIS), which has been a Russian invention to avoid the total disintegration of its sphere of influence after the demise of the USSR. The recent plan announced by Vladimir Putin, to set up the Eurasian Union, a bloc of countries belonging to the former USSR, means exactly this aim of reconsolidating the Russian sphere of interest in the area. Moscow most probably sees PfP (NATO) and the Eastern Partnership as an attempt by the West to counter Russian aims, thus projecting a zero-sum game vision, characterised by the lack of confidence among Russians and NATO states. The Russo-Georgian war led to NATO freezing its cooperation with Russia for a time, and the links only resumed in March 2009. In recent years, it became clear that a number of NATO member states do not want to irritate Russia by pressing for expansion or by vocally supporting the issue of an anti-missile shield (there was controversy between supporters of the project in the Czech Republic, Poland, US on one side, and German officials who were against it. One should remember the reluctance, even opposition of Germany and France in 2008-2009 against Ukraine and Georgia becoming NATO members). In other words, it appears that the rift occurred among NATO states. On the one hand, there are the supporters of NATO expansion by including young democracies of Eastern Europe, which also have a valuable geo-strategic position, even at the risk of antagonising Russia and, on the other hand, there are those who want to spare Russian sensibilities and 
interests and to reach a peaceful division of spheres of influence of the West and East.

There are political elites in NATO countries who question whether Georgia and Ukraine would add value as members of the alliance or would "export" their internal instabilities and conflicts with Russia to the broader area. Others questioned whether they were really "European countries". German Chancellor Angela Merkel is a good example, as she notoriously opposed the integration of Kyiv (Kiev) and Tbilisi into NATO. The strategic problem is serious: accepting Georgia as NATO member could in the end be accepted by Russia as it would not create a serious military threat to Moscow; accepting Ukraine would certainly generate a sense of existential threat to Russia's projects to enhance its sphere of influence in the Wider Black Sea Area. This trend will continue as the current leadership in Russia managed to survive the presidential elections of 2012, where Vladimir Putin easily defeated its contenders and exchanged offices with Dmitri Medvedev.

Enthusiasm and support for new members within NATO states are quite low, especially because there is some doubt concerning geopolitical and cultural affiliation of Kiev and Tbilisi to Europe and Euro-Atlantic space and more than that, NATO has yet to "digest" fully the expansion to the Western Balkans - Croatia and Albania became members in 2009. Barack Obama's presidential administration in the US seems more focused on areas like the Asia-Pacific and the Middle East than on the Caucasus and the Black Sea, and its huge efforts to stabilise Afghanistan consume a lot of resources and strategies. The European allies still do not forge a common strategy for the Wider Black Sea and seem unable to project their power to the East, excepting some form of normative and economic power via the Eastern Partnership. Europeans failed to increase their defence budgets to the "normal" level of $2 \%$ of their GDPs, while Washington announced a big reform of the armed forces, with an appropriation of 350-400 billion USD for a 10-year period and an emphasis on air and sea forces, not on infantry.

NATO officials have generally acknowledged that the future of Georgia as a member state should not be subject to the overall resolution of conflicts related to the separatist regions of South Ossetia and Abkhazia, as there is a risk that Russia would have hold an implicit right of veto over NATO's future enlargement. Some NATO states were reluctant to give the MAP to Georgia and Ukraine also because they probably feared that Russia would stop supporting NATO in Afghanistan and would encourage Iran's nuclear adventurism in the face of US hard line. Finally, Russia has taken the step so feared by the West, namely the recognition of South Ossetia and Abkhazia, thus questioning the legal territorial status quo instituted by the Helsinki Treaty of 1975. 
The war fought by Russia against Georgia in 2008, be it a "defensive" or an "offensive" one, had a clear and direct effect on NATO members in Central and Eastern Europe, whether from a strategic or a legal point of view, especially on the Baltic states, which hastily requested a contingence defence planning for the "Eastern flank" against a possible attack from outside. The Baltic States and Poland felt insecure as NATO did not deploy combat forces on their territory after accession but only some enabling infrastructure to support rapid reaction forces in case of necessity. Thus, the Eastern members believed that they were not adequately covered by the allied defence planning but only by the letter of Article V, which in theory and from a legal point of view, is enough to give security guarantees, but in practice led to some doubt about its effectiveness. As the Polish Minister of Foreign Affairs, Radoslaw Sikorski, stated in a November 2008 speech, "the conflict in Georgia put an end to an era in which one could go without the NATO guarantees with the likely expectation that one will never need them". He continued "we must make NATO guarantee(s) credible again!" and warned that the so-called "Medvedev doctrine" - the implied right of Russia to intervene for the defence of Russian ethnics in neighbouring countries even by military force if threatened - is similar to what happened in the past. Sikorski immediately cited Germany's invasion of Poland in 1939, when Moscow claimed it had to protect the non-Polish residents of Eastern Poland and in fact violated Polish sovereignty and territorial integrity. This is reminiscent of the $18^{\text {th }}$ century, when Russia invaded Poland under the pretext of protecting religious minorities. ${ }^{10}$ In January 2010, the NATO Military Committee eventually agreed on a regional defence plan for the Baltic states and Poland - the so-called "Eagle Guardian" mentioned by a WikiLeaks cable. Germany proposed this plan to defend the Baltic States and Poland, but Warsaw asked for additional measures like arming the Patriot missile system on Polish territory. ${ }^{11}$

Such talks regarding the collective defence planning for the Eastern flank eventually centred on the effectiveness and credibility of Washington Treaty's Article V and many politicians in Central Eastern Europe noted that not only postconflict reconstruction missions and peacekeeping are important, but also the collective self-defence, which is actually the essence of NATO intentions ever since the Cold War. American, Polish and Romanian insistence that Ukraine and Georgia be admitted as NATO members was met with resistance from Germany and France. Paris and Berlin especially feared the reaction of Russia, which traditionally considers Ukraine as part of Russia's "near abroad", thus in its immediate sphere of influence. Germany and France also stated that these two Eastern countries are consumers of security rather than providers and they do not bring any added value to the trans-Atlantic security. 
Psychologically, Russia seems to be a prisoner of the $19^{\text {th }}$-century geopolitics. Columbia University professor Robert Legvold tried to explain this behaviour,

Because the Soviet Union was not vanquished in war or those who managed its military establishment discredited, as was true for Germany and Japan after World War II, the country has found it difficult to separate itself from traditional ways of defining national security or even who poses a threat. ${ }^{12}$

As it is well known among some Western security experts, classical geopolitical theories with a "realist" basis"13 have a certain influence over the Medvedev-Putin tandem, in spite of their pragmatism and opportunism. These theories are based on the idea of restoring Russian influence on the former Soviet Slavic world by playing a zero-sum game against the West, as some decisionmakers were afraid that receiving Ukraine into NATO could be seen as an intolerable affront to Russia. ${ }^{14}$ In March 2009, the French Defence Minister, Hervé Morin, said that any expansion of NATO should take into account Russia's interests, only by holding consultations with Moscow. Morin's statement was registered on 17 March 2009, shortly after the French parliament voted France's return into NATO's military structures, which Paris had left in the 1960s. On 16 March 2009, a high-level US committee advised US president Barack Obama not to encourage Georgia and Ukraine to seek NATO membership, but to postpone this event and restore cordial relations with the Russian state. ${ }^{15}$ The "reset policy" launched by Obama's administration is based on making some geo-strategic compromises in order to reassure Russia of US benign intentions. However, after Vladimir Putin accused state secretary Hillary Clinton of interfering in Russia's domestic business and inciting opposition forces to huge street manifestations during the December 2011 elections, we think that the reset policy brought only limited results. If the Democrat Barack Obama would be defeated by the Republican M. Romney in the presidential election in USA, it is difficult to think that the reset policy will really be maintained.

According to public polls, the Georgians were in favour of joining NATO by over $70 \%$ in 2007; Ukrainians were only $40 \%$ for joining NATO and $54 \%$ against it in 2006, and a difference of just two per cent in favour of membership in $2008 .{ }^{16}$ Thus, the perspective of membership tended to increase the number of those favourable to that outcome. Moreover, NATO leaders probably realised that the rapid entry of Ukraine into NATO could precipitate an internal ethno-political conflict and could even lead to the breaking of territorial unity of this state. Military analysts wonder if Georgia and Ukraine, once admitted into NATO, would be 
effectively protected by Article V of the North Atlantic Charter in the case of Russian aggression, given the differences of opinion between allied countries. This scenario creates a serious military-political dilemma because it may call into question the very relevance and effectiveness of this collective defence organisation. Is it acceptable that NATO engages in peace-building and post-conflict reconstruction in Afghanistan, Kosovo and Bosnia if it cannot protect its eastern members against conventional aggressions? On the other hand, maybe Georgia and Ukraine were not admitted just because the allies knew they would not be ready and able to defend themselves in a dangerous situation? Other concerns for transAtlantic security regard the risk of cyber attacks and the issue of energy security. In 2006, at the NATO Riga Summit, Senator R. Lugar proposed that NATO take care of energy security infrastructures and corridors for defending its members, even by adapting Article $\mathrm{V}$ to this aim, a proposal, which obviously angered Russia.

It is difficult for NATO to deal with the issue of "frozen" conflicts (ethnic, political, territorial) in Transnistria, Abkhazia, South Ossetia and NagornoKarabakh, even if its members Romania and Poland are very interested in finding a diplomatic solution to the conflicts. ${ }^{17}$ Of course, NATO decision-makers are well aware that other states and institutional players are already involved in this issue; thus, they would agree with complementarity and not with duplication of efforts. The NATO Bucharest summit's final communiqué, in April 2008, spoke about the importance of the Greater Black Sea area. The leaders of these states admitted publicly for the first time the Black Sea as of strategic importance for NATO:

We reaffirm the continued importance of the Black Sea region for Euro Atlantic security. In this regard, we welcome the progress in consolidation of regional ownership, through effective use of existing initiatives and mechanisms. The Alliance will continue to support, as appropriate, these efforts guided by regional priorities and based on transparency, complementarity and inclusiveness, in order to develop dialogue and cooperation among the Black Sea states and with the Alliance. ${ }^{18}$

Political-military interest in this region remained high on NATO's agenda even after the Russian-Georgian war. In the final communique of the 2010 Lisbon Treaty, the leaders of the allied states remarked:

Security and stability in the Black Sea region continue to be important for Euro-Atlantic security. We welcome the progress in consolidating regional cooperation and ownership, through effective use of existing initiatives and mechanisms, based on transparency, complementarity and inclusiveness. We encourage these efforts and 
stand ready to support them, as appropriate, based on regional priorities and dialogue and cooperation among the Black Sea countries and with the Alliance. ${ }^{19}$

Eventually, at the Lisbon North Atlantic Council Summit in November 2010, chiefs of states and governments of NATO states decided to invite Russia to take part in the anti-missile shield that NATO was to develop to complement the American shield. It was a historic step towards reconciliation, but, no immediate response followed. Subsequently Russia asked for legal guarantees and a firm commitment from the US that the shield would not be used against it. The US refused. Then Moscow asked NATO to have a co-decision right in working on the NATO shield, and it was again refused. Then, in November 2011, President Medvedev threatened to install anti-radar missiles and enhanced penetration warheads in the Russian-owned Kaliningrad area to balance the US's missile and shield capabilities in Romanian and Polish territories and the Mediterranean. NATO's Chicago Summit from May 2012 unfortunately did not bring the necessary clarification between Russia and the NATO states. The US anti-missile shield had to cover at least the eastern shore of the Black Sea (and possibly also South Caucasus and the Crimea), and then the NATO shield would protect the south-eastern flank. This explains Russian sensitivity to deal with this issue. ${ }^{20}$

The European Union also has a strong cooperation framework in the WBSA - the Partnership and Cooperation Agreements (PCAs) offered to the newly independent states, members of the Commonwealth of Independent States (CIS), and, in the case of the Russian Federation and Ukraine, the EU also proposed "common strategies" for individual countries. Russia and the EU have, since June 2010, a partnership for modernisation encompassing issues like economy, social welfare, science and engineering, education, and innovations. ${ }^{21}$ However, issues like human rights and prisoners' rights in Russia (the Kodorkovsky case) prevent a stronger EU-Russia link. One of the results is Russia's lack of success in getting a visa-free regime for its citizens traveling in the EU. In 2011-2012, the Republic of Moldova was trying to get a stabilisation and association agreement with the EU, as a first step towards a possible integration, being considered the most reformist exSoviet state. The EU eventually addressed all the WBSA states through the Eastern Partnership (EP), launched in 2009, and subsumed it into the European Neighbourhood Policy (ENP). The EP has been designed for the needs of Eastern European countries like Armenia, Azerbaijan, Belarus, Georgia, Moldova and Ukraine, in order to help them get closer to EU political, economic and security standards. Visa liberalisation, free trade areas and political association are the main goals. The main goals are to help those states to democratise, modernise, become rule-of-law entities end enhance their domestic and external security capabilities, but 
also to integrate them gradually into the European single market. ${ }^{22}$ The aim is to have a so-called "neighbourhood economic community" and encourage free movement with this space via the mobility and security pacts. However, the EP and the ENP do not grant EU full integration; in fact, they are rather substitutes for that. Because of the economic crisis hitting the Euro space and the events of the Arab Spring, the EU did not give all the necessary funds for the Eastern Partnership's functioning. Instead, countries of the South (Egypt, Tunisia, etc.) were preferred. The action plans and the Comprehensive Institution Building (CIB) Programme cannot be built without these funds provided through the European Neighbourhood Instrument Policy and secondarily by the Neighbourhood Investment Facility (NIF) and the Cross-border Cooperation $(\mathrm{CBC}){ }^{23}$ The last two are trans-national cooperation programmes by EU regions and neighbouring states sharing a common border. $^{24}$

NATO and EU remain the pillars of the West in the Wider Black Sea Area, a pole of stability and confidence, promoting democracy, rule of law, protection of human rights and the territorial integrity and sovereignty of all the local states. The only remaining problem is to see if these two institutions would eventually set up a "division of labour" in order to increase their effectiveness and avoid duplications and the wasting of resources. ${ }^{25}$ Unfortunately, there is still no "unitary voice" speaking on behalf of the West when there are high strategic stakes in the Wider Black Sea Area. For both EU and NATO, this could lead to either decision-making paralysis or to the temptation to create small "coalitions of the willing" within these bodies. When France decided in the summer of 2010 to sell Mistral-class military vessels to Russia, ${ }^{26}$ this has been depicted by Paris as normal business with a NATO partner while it was deplored by Poland and the Baltic states as a negative blow against allied security in the Black Sea. In fact, Russian military commanders praised the Mistral boats for their usefulness in conflicts like those opposing Moscow to Tbilisi and they did not make a secret of the fact that they would be used in the Crimean basis of Sevastopol on the Black Sea, maybe also in the Baltic Sea. In fact, it seems that Russia is skilfully playing its strategic cards - cheap energy, access to its huge market, counter-balance of US power - to attract some Western states like France and Germany and break up the Western unity. Russia managed to negotiate transfer of weapons bilaterally with some NATO members, thus breaking NATO capacity to speak with one voice on strategic issues. ${ }^{27}$

Of course, the famous "Western unity" has not always been a reality on the field, even since the Cold War. One should not forget episodes like French President De Gaulle distancing himself from the USA and getting France out of the NATO military structures in the 60s, or France blocking the United Kingdom's access to the European Economic Communities for a long period. A special case is that of 
Turkey, a NATO member and candidate to EU integration in the long run, but without any certitude. Having a territory of $780580 \mathrm{~km}^{2}$, and 76,8 million inhabitants, Turkey is a very important regional player. After 2001, when it opposed US invasion of Iraq, Turkey became more and more reluctant to support Western aims in the Black Sea Area and Eurasia and began to get closer to Russia. The Minister of Foreign Affairs Ahmed Davutoglu became well known for his book Strategic Depth in which he supports a multi-vectorial foreign policy, a "zero conflicts with the neighbours" strategy and a more assertive regional role for his country. ${ }^{28}$ The "neo-Ottoman" orientation of Turkey and the de facto partnership with Russia produced irritation in the US and many EU and NATO states. However, Turkey is heavily dependent on Russian gas and the Blue Stream I and II pipelines are vital for the country's economy. ${ }^{29}$ Turkey aims to become an energy hub in Europe; hence, the temptation to play the Nabucco pipelines against South Stream and EU versus Russia. More than that, during the Russo-Georgian war in 2008, Turkey opposed a US proposal to send cruisers through the Black Sea Straits to support humanitarian missions in Georgia. Thus, a NATO member blocked other NATO colleagues from using the Straits invoking the Montreux Convention stipulations. Supported by the USA, Turkey tried to normalise its diplomatic relations with Armenia, non-existent since the 90s, when Ankara supported Azerbaijan against Armenia on the issue of Nagorno-Karabakh. Armenia wants Turkey to recognise the genocide against the Ottoman Armenians committed by orders of the Turkish state authorities before World War I, while Ankara was under pressure by Azerbaijan not to accept a normalisation of diplomatic relations with Armenia without an Armenian compromise on Nagorno-Karabakh. Many Europeans and Americans are afraid that the current AKP-ruled Turkey may become more and more an Asian/Muslim power and disengaged from Europe, getting a too aggressive regional profile, which would reduce its chances of EU membership. ${ }^{30}$ On the other hand, Turkey wants to play a prominent role in the Middle East and the Wider Black Sea Area, seeing itself as a provider of peace and security in those areas. Thus, when Ankara agreed that Syrian armed guerrillas fighting against Bashar Al Assad's regime in 2011 had a safe haven on Turkish territory, this was seen in the light of a Turkish plan to restructure the security architecture in the Middle East. Turkey only reluctantly accepted NATO's campaign in Libya in 2011, but then invoked the responsibility to protect $(\mathrm{R} 2 \mathrm{P})$ in the case of civilians from Syria and threatened $\mathrm{Al}$ Assad's regime! It is worth remembering that Turkey is a Sunni Muslim state, while the ruling elite in Syria is Alawi (Shia) and the opposition is mainly Sunni.

Turkey will probably not become an ally of Russia but their partnership built on mutual and individual interests could become stronger and even turn into a de facto condominium in the Black Sea, as both powers actively oppose the 
internationalisation of the Black Sea (by the USA and NATO) and the Western presence there.

\section{The Eurasian Vision: Russia's Strategy}

For some centuries, Russia has been the heart of an empire, maybe the largest Eurasian empire except the Mongol empire during the $13^{\text {th }}$ and $14^{\text {th }}$ centuries. Territorially it expanded first to the east then to the west, being contained by the Western powers during the Crimean War, the First World War and reaching its zenith during the time of the Soviet Union. ${ }^{31}$ The ideologies which stood behind this imperial entity were first a mixture of Christian Orthodox faith (the myth of the "Third Rome") and Slav nationalism, then Marxism-Stalinism and after 1991 when the USSR broke up, nationalism and pan-Slavism. Between 1991 and 1999, Russia has been a relatively weak geopolitical actor, a country with political, ethnic and economic vulnerabilities. Vladimir Putin then became president and the "strong man" image of Putin brought changes. Putin centralised the state power and exploited its main advantages such as huge reserves of natural energy and the weapons market. This could lead to a partial recovery of the great power status, which seemed forever lost after the end of the USSR.

For Russia, the years 2000-2008 represented a period of success and increased military strength, economic power and geopolitical successes. President Putin's second term during 2004-2008 was characterised by spectacular growth, approximately $8-9 \%$ per year, based mainly on increasing fuel prices and export of armaments. Living standards improved and macroeconomic indicators changed, although serious discrepancies between rich and poor remained significant. ${ }^{32}$ However, the war against Georgia and the world economic crisis put an end to the huge economic expansion in Russia, as much of the foreign investments withered away. The Wider Black Sea Area remains a region of interest for Russia, because of its historic tradition, the existence of some former Soviet states there and the need to sell oil and gas to the West using this area for transit. ${ }^{33}$ The Caucasus-Central Asia area is very important as an energy-providing source, as the Middle East, the Persian Gulf and Africa are seen by the USA and some Western states, such as the UK and France, as unstable and dangerous regions. At the rate that oil and gas are diminishing it is possible that by 2020 , these resources would represent $37,9 \%$ and $28,5 \%$ of the world energy consumption respectively. Russia, Kazakhstan, Azerbaijan and Turkmenistan are the most important producers of gas and oil in that region. In the Wider Black Sea Area, Russia is the main provider of gas, followed by Azerbaijan, while Turkey, Ukraine, Bulgaria, Romania, Moldova and Armenia are the main consumers. Russia sells about $25-30 \%$ of the imported gas to the EU and has a near monopoly on the energy transportation corridors. The big Baku-Tbilisi- 
Ceyhan oil pipeline is well functioning, together with its "sister", the Baku-SupsaErzurum gas pipeline, but only the building of the Nabucco gas pipeline between Azerbaijan and Austria plus the extension of Odessa-Brody pipeline to Plock would really diminish EU's dependence on Russian gas.

After 2000, Russia realised that it could have leverage on EU states by acquiring sufficient energy infrastructure in many European states but also by denying them the right to do the same in Russia. So, Russia refused to ratify ${ }^{34}$ the European Energy Charter in order not to be asked to give equal treatment to European companies in the Russian share of the energy market. Many EU states are heavily dependent on gas and oil imports from Russia, for instance Greece, Bulgaria, Poland, Hungary and the Baltic States. Russia deployed the "energy weapon" several times against neighbouring countries to ensure that they comply with its demands. In January 2009, the conflict between the giant Russian gas company Gazprom and Ukraine produced a cutting off of the gas supply for many EU states like Poland, Romania and the Czech Republic. The EU's plan to build the Nabucco gas pipeline from Azerbaijan to Turkey, Bulgaria, Romania and Austria is competing with the South Stream project, a big Russian initiative for building a gas pipeline crossing the Black Sea and reaching Bulgaria, Serbia, Hungary, Italy, Austria and Greece. Another rival is the Trans-Anatolian pipeline involving Azerbaijan and Turkey. Nabucco would be operational in about 6-10 years' time and could bring 25-32 billion cubic metres of gas from Azerbaijan but also Iran, Iraq and Egypt to Western Europe. The project will be co-funded by the World Bank and the European Bank of Reconstruction and Development by $50 \%$ of the total costs - about 8 billion euros. If the "classical" Nabucco fails, at least the new Nabucco West version should be built. It would pass through Bulgaria, Romania and Hungary and then Austria. Its total length would be $1300 \mathrm{~km}$.

In order to prevent Azerbaijan from selling most of its gas to EU countries, Russia signed an agreement with its small Caucasian neighbour in September 2010 to buy 2 billion cubic meters of gas in 2011, a $100 \%$ increase compared to 2010 . Gazprom is $50,2 \%$ owned by Russia but is widely seen as a geostrategic tool for Moscow. The company holds the biggest world gas reserves, estimated at more than 182 billion USD and exports about 160 billion cubic metres of gas to EU states annually. However, it has big operational costs and its infrastructures are outdated and worn out, and the company desperately needs foreign money for investments. Except China, only the West could invest so much money in the Russian energy sector. Energy has been a main leverage of Russian power, as the EU states rely on Russian gas for at least $30 \%$ of their domestic and industrial needs. Of course, Russia is also dependent on the EU market, the Europeans being the number one customer at least for Russian gas. The issue of energy domination is also part of 
Russia's national role conception and more generally is incorporated in the belief system of decision-makers. Russian decision-makers and the public opinion perceive energy as a big advantage for their country, allowing it a huge leverage on Western powers, so Russian decision-makers want the degree of Western dependency on Russian energy to increase. When they see Romania, Poland and the Baltic states insisting on favour of the Nabucco gas pipeline project and rejecting the idea of participating in the alternative Russian-proposed South Stream, they clearly perceive this as a hostile action.

However more importantly, from a traditional security point of view, in the 1990s, Russia felt vulnerable to NATO and EU enlargement, and threatened by a new "unipolar" international system dominated by the USA. ${ }^{35}$ Thus, the main goal for Moscow after the Cold War has been to block NATO expansion in a region labelled as "direct neighbourhood" for Russia, a region of special interest. Furthermore, they tried to prevent the Western powers, especially the USA, to come into this area and establish privileged relations with local ex-communist states. ${ }^{36}$ Russia could not block NATO's expansion in 1999 into Poland, the Czech Republic and Hungary but then vehemently opposed the idea of receiving Ukraine and Georgia in the Western alliance. Moscow threatened the West with a new Cold War (a military arms race) and also threatened these former Soviet countries with internal destabilisation as Ukraine has a huge Russophone minority in the East and a Russian military basis in the Crimea while Georgia has two "frozen conflicts" on its territory, both supported by Russian interventions: South Ossetia and Abkhazia.

Traditionally, Russia had a defensive psychology: historically it feared invasions from external powers and tried to set up buffers to be protected against people like Tamerlane, Napoleon I and Hitler. ${ }^{37}$ More than 60 years ago, the famous "hawkish" US diplomat George Kennan stated in his famous "Long Telegram":

... at bottom of Kremlin's neurotic view of world affairs is traditional and instinctive Russian sense of insecurity. Originally, this was insecurity of a peaceful agricultural people trying to live on vast exposed plain in neighborhood of fierce nomadic peoples. To this was added, as Russia came into contact with economically advanced West, fear of more competent, more powerful, more highly organised societies in that area. ${ }^{38}$

Thus, Russians developed a defensive psychology and behaviour, always fearing foreign invasions and malign interferences. This buffer area of the WBSA also allows the control of energy transit, and energy together with weapons sales constitutes the majority of Russian exports, at least in terms of earned money. Thus, the symbol of the neighbouring states as buffer area is strongly anchored in the 
Russian collective spirit together with the obsession with foreign aggression. It is therefore no wonder that the new military doctrine of the Russian Federation (2010) insists on the need for defence against foreign aggressors and that it puts the nuclear weapons on the first plan.

Russia's well-known foreign policy expert Andrei Tsygankov warned against the Western tendency to punish Russia and to press it for huge reforms:

Punishing or ignoring Russia is not likely to discipline it, however. Russia continues to be in a position not to yield to the pressure of tough rhetoric and isolationist actions from the West. Against expectations, such policies are likely to strengthen anti-Western Russian nationalists and push Russia further away from the Western nations. Nationalists need an image of the West as a threat - they are dependent on it for their own survival. They will only be grateful to Western politicians, like Cheney, for assisting them in constructing such an image. Until the West becomes a key reference point for Russia, Western isolationism will be counterproductive in influencing the Kremlin. ${ }^{39}$

From the Russian point of view, Western states are bifurcated into two categories: those who are friendly or could become sympathetic toward Russian interests and those who oppose Russia and could be seen as potential enemies. Romania is seen as a "revisionist" country, belonging to the group of the US's close allies, a state wanting to limit Russia's power in the Wider Black Sea Area, to expand US anti-missile protection in the East, eventually to "extract" Moldova from the Russian sphere of influence and reunify it into Great Romania. ${ }^{40}$ Classic security needs made Moscow very careful of the regional balance of power between itself and the West. One of the Russia's instruments in the Black Sea area is the Collective Security Treaty Organisation. The initial document allowing its setting up was signed in May 1992 in Tashkent (the capital of Uzbekistan) by a group of former USSR countries but some of them only became members in 1993, namely Armenia, Belarus, Kazakhstan, Kyrgyzstan, Georgia, Russia, Tajikistan, Uzbekistan and Azerbaijan. Countries such as Moldavia, Turkmenistan and Ukraine, did not take part in the treaty, claiming neutrality. The Collective Security Treaty was only registered at the UN Secretariat in November 1995. Later, in 1999, member countries Azerbaijan, Georgia and Uzbekistan withdrew from the treaty, but Uzbekistan came back again and finally left in 2012 .

After the leaders of the member states had decided to turn this security structure into a permanent and more binding arrangement in 2002, the Collective Security Treaty Organisation (CSTO) was registered at the United Nations as a 
regional international organisation on 26 December 2003, in accordance with Chapter VIII of the UN Charter. Officially, the CSTO is not an "Asian NATO" or even an "anti-NATO" looking for military expansion by hard security measures and to counter Western expansion to the east. CSTO Secretary-General Nikolai Bordyuzha, a Russian general, denied in 2005 that Russia had plans to set up bases in the Central Asian region and asked that the Collective Security Treaty Organisation (CSTO) be able to be more proactive when dealing with dangerous crises.

The ethnic war, which affected the southern area of Kyrgyzstan in June 2010, proved the ineffectiveness of the CSTO, which was unable to decide on sending forces to put an end to the conflict between ethnic Kyrgyz and Uzbek there, which killed hundreds and forced tens of thousands of refugees to go to the Uzbek border to escape the violence. This came about despite the fact that the CSTO previously adopted a package of additional military and legal instruments to enhance its military capabilities, especially the ability to intervene militarily within a member country which is the victim of a domestic crisis. The CSTO has been shaped as a collective security provider, protecting its members from outside threats. ${ }^{41}$ However, it seems helpless when dealing with peace-keeping. Russia is reluctant to agree with this kind of mission, as it recorded a similar intervention in Kyrgyzstan, in June 1990, during the Soviet Union's final era. Russia feared both a civil war in this country and an inter-state war between Kyrgyzstan and Uzbekistan. The CSTO also has a Collective Rapid Reaction Force and is responsible for a peacekeeping force of 3500 people. As a reaction to CSTO's perceived lack of effectiveness and probably also because its government wanted a balance between the interests of Russia and the USA, Uzbekistan decided in July 2012 to withdraw from the CSTO. Expressing the general Russian disappointment, a Russian analyst, Vadim Kozyulin, commented as follows: "The United States will make Uzbekistan its strategic ally, will provide financial and military assistance, assume some security guarantees, close its eyes to human rights violations."

One should remember that the USA still operates the military base at the Manas Airport outside Bishkek, the capital of Kyrgyzstan. NATO countries will need the support of this Central Asian state when withdrawing military equipment from Afghanistan in 2013-2014. On the other hand, more than a decade ago, the same country withdrew from Guam because of Russian pressures; thus, one could identify a general tendency for Uzbekistan to avoid strong institutional security commitments.

At the CSTO Summit in December 2010, the heads of state signed a new document, entitled "On the order of response to crisis situations", which deals with 
preventing or managing crises using preventive diplomatic, humanitarian aid and even military measures. Russia wants the member states to expand the defence industrial cooperation and to create an integrated air defence network encompassing all the members of CSTO. The CSTO is heavily controlled by the Russian Federation, at political and military levels. Most of the troops are Russian and the budget is provided largely by Moscow. As the military analyst Richard Weisz put it,

... furthermore, Russian officials have used the CSTO to legitimise their dominant military presence in Central Asia. For example, Russia justifies its controversial and rent-free possession of its air base in Kyrgyzstan on the grounds that it provides air support for the entire CSTO region. ${ }^{43}$

After 2004, Moscow began to push the CSTO to request the gradual withdrawal of American bases from Uzbekistan (Karshi-Khanabad) and Kyrgyzstan (Manas). ${ }^{44}$ In 2005, Uzbekistan asked US forces to withdraw from its territory and Washington agreed. However, in 2010, the US wanted to develop its military facilities by building military training centres in Tajikistan and Kyrgyzstan. This would allow a redeployment of important military facilities from Afghanistan in Central Asia and a better capacity to intervene in Afghanistan. ${ }^{45}$ The CSTO had no military bases of its own; the member states supplied the necessary bases. As a general rule, Moscow felt it increasingly difficult to accept "interference" by the West - i.e. NATO, EU, US - in countries like Ukraine, Moldova and Georgia while at the same time encouraging the leaders of separatist movements in former Soviet states to take action against the respective states. Like its smaller neighbours, Russia used the "carrot-and-stick" strategy: it offered economic benefits to those who had a friendly attitude (Belarus, Armenia - preferential prices for oil and gas) and imposed economic sanctions and higher oil and gas prices on countries, which objected to its right to interfere in their domestic affairs (see the economic embargo on Moldovan wine and mineral water and on wines from Georgia which began in 2006). ${ }^{46}$

The so-called "coloured revolutions" in Ukraine and Georgia were deeply disturbing for Moscow, and the Russian political class tended to overstate the role the US played in these episodes. Russia feared that US-sponsored groups in those countries would decisively defeat their pro-Russian competitors and eventually push these states into the western orbit. At the same time, the "Russian threat" was used by Georgian President Mikhail Saakashvili in his struggle against the domestic opposition, with relevant episodes of the arrest of pro-Russian spies and conspirators. Thus, maintaining the "frozen conflicts" had as an indirect effect, perhaps intentionally, the impossibility of democratic consolidation within Georgia and Moldova. ${ }^{47}$ As long as the political opposition is demonised and accused of 
being a Russian tool or "fifth column", it is impossible to agree with the democratic rule of power rotation. ${ }^{48}$ Russia managed to persuade some NATO countries not to provide a Membership Action Plan (MAP) to Georgia and Ukraine, and the war with Georgia in 2008 prevented Tbilisi from preparing for short-term NATO membership. Of course, it would be an exaggeration to say that the refusal to grant the MAP was a "green light" for the aggression committed by Russia. ${ }^{49}$ However, it is likely that Moscow saw this event as a sign of weakness. If, from a military point of view, it is difficult to say who was the real aggressor, from an international law perspective it is obvious that Russia bluntly violated Georgia's sovereignty and territorial integrity. ${ }^{50}$ Sure enough, the Russian minorities in former Soviet space must be protected, but only a few people think it is normal to invade sovereign states to make them comply with human rights. If the "responsibility to protect" (R2P) doctrine still exists, it is important in any case not to abuse it and to intervene under the umbrella of multilateral international organisations at all times, not alone. At global level, the United Nations is the most legitimate R2P provider.

The war against Georgia had multiple effects on Russia. On the one hand, it has led to the effective territorial fragmentation of the small South Caucasian state, while on the other hand, from Moscow's point of view, the war served as a "lesson" for Azerbaijan and Moldova should they ever try to use force to resolve their own frozen conflicts. The war illustrated both the success of big powers against their small neighbours as Georgia was literally crushed, but also the surprising vulnerability of the Russian military machine, which in some areas was put into a delicate situation by its small neighbour and foe. The war made the poor commanding capacity of some Russian officers and serious vulnerabilities in logistics obvious. ${ }^{51}$ The Georgians managed to shoot down about 4-8 aircraft and the Russian military airplanes demonstrated inaccuracy in their strikes, a fact which seems to have been caused by the poor quality of many pilots and the lack of unmanned aerial vehicles (UAVs), whose production was halted in 2006. Thus, many doubts were expressed concerning Russia's ability to keep pace with the Revolution in Military Affairs (RMA), in which the US and some EU countries excel and where China has made significant progress. The global navigation satellite system (GLONASS) also seems not to have functioned properly, thus making it difficult for the Russian units to clearly distinguish the enemy from their own forces, and hampering communication between different types of units in the field. ${ }^{52}$ Defeated and humiliated, Georgia left the Commonwealth of Independent States in 2009, thus creating a precedent for future abandonments. More than that, Georgia managed to delay Russia's membership in the World Trade Organisation (WTO) for more than two years. Only in December 2011 was Russia invited to become a member of the WTO, after a compromise mediated by the USA and the Baltic states. 
Internationally, Russia has been marginalised by the West for a while, and even the People's Republic of China and CIS countries have refused to recognise the new diplomatic secessionist states - South Ossetia and Abkhazia - despite Moscow's insistence. When Kosovo proclaimed its independence from Serbia in 2008, Russia vehemently protested and asked the other states to abstain from recognising the new country. At the same time, Moscow stated that a new juridical precedent was set and that in the future it would recognise other separatist states, thus laying the guilt on those Western states which supported Kosovo's independence. Ukraine, or rather its pro-Western camp, was radicalised and it accused Russia of using its military naval base at Sevastopol to send vessels against Georgia. President Victor Yushchenko announced solemnly that Russia would not be granted a prolongation of the contract for the basis in Sevastopol after 2017 and "warned that Ukraine might not permit Russian Black Sea Fleet ships sent to patrol around Abkhazia to return to port". ${ }^{33}$ Some local and foreign sources have even stated that Ukraine had provided logistical support to the embattled Georgians, in addition to diplomatic support. ${ }^{54}$ However, after President Yanukovych became the new president, Ukraine agreed to extend the fleet agreement with Russia for another 25 years, and the Supreme Rada (Parliament) proclaimed the country neutral ("no blocs policy"), thus preventing the likelihood of NATO membership. The only positive aspect for the Russian government was maintaining or even enhancing public confidence in the decisions of leaders. According to surveys, over $50 \%$ of Russians have stated that they considered the military campaign against Georgia correct while the Georgian state is described by the media and many Russian officials as a US "Trojan horse" in Eurasia, the main "enemy" for Russia in the Caucasus.

Besides trying to block NATO expansion, Russia has spared no efforts to prevent the construction of the US missile shield. In December 2007, Moscow has "frozen" its participation of the Conventional Forces Treaty in Europe (CFE), suggesting an increased lack of confidence between Russia and NATO states. Then, through the voice of Defence Minister Sergei Ivanov, the Czech Republic and Poland were threatened that they could become targets of "legitimate" Russian strikes in the event of war. Russia always insisted that the US anti-missile shield would produce instability and an escalation of the arms race through the mechanism of a security dilemma. In an attempt to make the US give up Poland and the Czech Republic as best places to install radars and interceptors, Russia has "offered" to share with the USA a base in Gabala (or Qabala) (Azerbaijan), but the US did not accept the idea and it is unlikely to agree with joint control of this location for the theatre-based missile defence system. Certainly, Washington wants neither to share very sensitive technology with Moscow, nor to be constrained in its decisions by 
another country, which is not properly an ally. Nevertheless, there are NATO strategists who would like a military base in Azerbaijan, close to Iran and Russia, but there will be a price to pay to Moscow.

Between August and December 2008, after blocking its CFE participation, Russia brought some additional forces into South Ossetia and Abkhazia, creating permanent military bases there. In fact, the Russian leaders seemed to realise that the Russian state had lagged behind the West in terms of conventional weapons, because NATO countries had advanced rapidly towards the RMA. This perhaps explains the Russian insistence on nuclear weapons as the ultimate deterrent factor. The hostility to the US missile shield was generated by the fear that the shield might abolish the nuclear deterrence capability of Russia, which would then lose its status as a great power. However, as I already mentioned, at the November 2010 NATO Summit in Lisbon, Russia was invited to take part in the future allied anti-missile shield and the Russian Ministry of Defence did not rule out this scenario.

Unfortunately, the NATO summit in Chicago (20-21 May 2012) showed the extreme difficulty of an agreement between US/NATO and the Russian Federation because the US Senate still does not want to provide legal guarantees to Moscow that the shield would not be used against Russian missiles. As a consequence, Russian President Putin did not take part in the summit. Most of the NATO states would agree with a system of separate but coordinated anti-missile capabilities, but not with a common system because they are against giving Russia, a non-NATO state, the right to co-decision. Unable to reach consensus, both Russians and Americans hoped that this would be possible after their presidential elections in 2012, but Russia wants to install Iskander short-range missiles in the Kaliningrad enclave, which is situated between Poland and Lithuania and the Baltic Sea, thus inside NATO-covered territory. This is a reaction to Obama's European Phased Adaptive Approach (EPAA) to missile defence in Europe based on the Aegis SPY-1 radar and Standard SM-3 missile interceptor to be located in the Mediterranean, and also in Romania and later in Spain and Poland, with a large radar station among others in Turkey, etc. ${ }^{55}$

In the summer of 2008 and again in 2009, former President Medvedev of Russia proposed a pan-European security treaty based on "multipolarity" in international relations and the implicit recognition of the legitimate spheres of interests. Several European countries, especially France, Germany and Italy, have shown interest in the idea; however, others, particularly those in Northern and Eastern Europe, have expressed scepticism and distrust. In November 2009, Russia formally presented a draft of the so-called "European Security Treaty" to all Organisation for Security and Cooperation in Europe (OSCE) member states but the 
treaty also addressed NATO and EU states. The main principles of this text are those of not resorting to force for aggressive aims, non-interference in domestic affairs of other states (including the commitment not to help states, which actually infringes on the security of the others) and reasserting the role of the UN Security Council as the sole legitimate instance to deal with military conflicts. One could also find trustbuilding measures among states, for instance mutual consultations and dialogue, the right of member states to receive information from other states who take military measures that could affect their security. If one state is attacked, the other could provide it with support until the UN Security Council would take the necessary measures for defence. According to Article 10 of the draft, the eligible members for this new organisation will be all the states "between Vancouver and Vladivostok", but also regional organisations like the EU, NATO, OSCE, CIS and CSTO. ${ }^{56}$ The draft treaty ${ }^{57}$ alarmed some of the Western states because it required of members that previous obligations should not contradict the new treaty. Thus, in case of possible aggression against a NATO member, the Alliance could not intervene because the Washington Treaty was no longer valid in the face of the new panEuropean and Eurasian organisation. ${ }^{58}$ The collective defence and self-defence risk to be undermined by the new structure thus enhanced the vulnerability of some small states, which were confronted by powerful neighbours.

Because of the aggression committed against Georgia, the frequent incidents that suggest the use of energy as a "geopolitical weapon" to intimidate other states seriously worried the importing countries from Europe. More than that, the harsh threats about "risks" arising from the receipt of Georgia and Ukraine into NATO, the pan-security project in Europe and Eurasia, which does not seem credible for most NATO states, but rather an attempt to test the reaction of external partners and maybe even to speculate on certain divisions of the NATO countries, were other factors which increased the trust among Russia and the West.

Negotiating a new organisation with members from three continents, or about fifty states, will take a lot of time and effort as all of them have to sign and ratify the treaty. And there may be no real guarantee that Russia will change its behaviour in the end. ${ }^{59}$

In retrospect, Russia appears to be an international actor with a highly centralised management, a strategic thinking paradigm based on the lessons of "realism" in international relations in calculating gains and cost reduction, with a classical geopolitical vision, rooted in the desire to recover at least some power elements and prestige of the former USSR. Faith in the economic and military power based on natural resources has generated rather aggressive action abroad and the desire to control neighbourhoods by maintaining spheres of influence, by playing off 
Russian power against weaker neighbours and isolating them. According to some area experts, Russia seems to have an interest in maintaining the so-called "frozen conflicts" in Transnistria, Nagorno-Karabakh, South Ossetia and Abkhazia unresolved. ${ }^{60}$ By keeping some 2000 military forces in Transnistria, a separatist entity within the Republic of Moldova, and declaring them "peace-keeping forces" while the Moldovan government sees them as occupation forces, by recognising South Ossetia and Abkhazia as independent states and installing military bases there (thus violating Georgia's sovereignty on its own territory), and by refusing the continuation of the OSCE mission into Georgia, Russia in fact prevents the peaceful settlement of these conflicts, thus keeping Moldova, Georgia, Armenia and Azerbaijan weak and isolated, unable to leave the Russian sphere of influence. ${ }^{61}$ According to some credible sources, Russia rightly believes that the US-dominated unipolar international system will come to an end sooner or later and that Russia has to prepare for a post-American world, including trying to reassert its regional influence. $^{62}$

In the end, nothing is bound to happen following one pessimistic scenario in international relations (the classical zero-sum game); thus, Russia could evolve towards more cooperative behaviour in the future and become a real security partner of the West. However this depends mainly on Russia's domestic political and economic developments. The West, arguably, should try to influence such an evolution positively, without punishing or harassing Russia.

\section{The Regional Security Structures}

The institutional attempts to increase cooperation and mutual trust among the countries in the Wider Black Sea Area should be mentioned. The Organisation for Security and Cooperation in Europe is the only regional organisation dealing with a broad agenda of security issues, from political-military to economic, cultural, environment, human rights, minorities and other related issues. Created in 1973 at the Helsinki Summit under the name CSCE, the initiative evolved after the Cold War into a real trans-Atlantic organisation dealing with the management of regional conflicts and post-conflict reconstruction, democratisation process and defence of human rights. Countries from Western, Central and Eastern Europe, the USA and Canada, but also countries from Central Asia are members of the organisation. However, because of the decision-making process, which requires unanimity of the members of the Ministerial Council, it is almost impossible to take effective decisions concerning the thorniest issues like territorial secessionism, foreign military presence in some member states, and arms race consequences. 
At the 1999 OSCE Istanbul summit, Russia committed itself to withdraw its forces from Transnistria and Georgia but after 10 years, in 2010 at the Astana Summit, there were no practical outcomes yet. Almost 2000 soldiers are still in Transnistria. Russia created permanent military bases in South Ossetia and Abkhazia and the Minister of Foreign Affairs of Russia, S. Lavrov, stated in Astana, "there can be no talk whatsoever of the territorial integrity of Georgia within its former boundaries". ${ }^{63}$ At the same time, in November 2010, the NATO Summit in Lisbon issued a statement declaring that the territorial integrity of Georgia was inviolable. Thus, the issue of forbidding the use of force among states, part of the Helsinki OSCE Decalogue, is interpreted in various - even contradictory - ways by Russia and other OSCE members

The revisited Treaty on Conventional Armed Forces in Europe (CFE-1999) ${ }^{64}$ is another thorny issue which hinders the emergence of a pan-European security agenda. Because Russia did not fulfil its commitment to withdraw its forces from Transnistria, the NATO states refused to sign and ratify the revisited CFE treaty. In 2008, Russia reacted by "freezing" its participation in the CFE. Russia was discontented with the US decision to build an anti-missile shield to protect European and American territories against possible future attacks, from "non-European" territories, which by implication reflected on Russia as a non-member of NATO. In 1992, the OSCE/CSCE furthermore created the Minsk Group (Russia, US, France as co-chairs, as well as Armenia and Azerbaijan) to deal with the Nagorno-Karabakh conflict between Armenia and Azerbaijan, but its success is almost non-existent! More than that, Azeri leaders do not really trust the co-chair states because they all have important Armenian minorities, which traditionally put pressure on the governments to ask for more concessions from Baku. In addition, Russia has a military cooperation agreement with Armenia, plus military bases there.

The Corfu process, adopted in June 2009 by OSCE states, foresaw an openended process of enhancing Eurasian security. So far, visible outcomes because of Russian sensitivities are limited. OSCE is seen by many analysts and politicians as a bureaucratic and ineffective structure, unable to overcome the decisional paralysis. In 2009, Russian President Medvedev proposed a new pan-European and panEurasian security organisation, thus suggesting the wish to abolish the OSCE. However, the USA and most of European OSCE members do not agree because OSCE is a wide forum of dialogue and cooperation and arguably it is possible to reform and improve it.

The Organisation for Democracy and Economic Development (previously known as GUAM) has brought together Azerbaijan, Moldova, Georgia and Ukraine since 1997, when the Consultative Forum was established. The GUAM ${ }^{65}$ charter 
was signed in June 2001 by these countries and also Uzbekistan, which later withdrew. The goals of this institution were to enhance regional cooperation, increase security for all participants and enhance economic exchanges all across the region. The Western Europeans and North Americans often saw GUAM as a structure designed to counter Russia's influence in the Wider Black Sea Area, in spite of GUAM members stating their will to develop cooperative relations with Russia and Russian-led CIS.

Another important structure is the Black Sea Economic Cooperation (BSEC). This regional organisation came into being on 25 June 1992 in Istanbul, when eleven heads of state or government (Albania, Armenia, Azerbaijan, Bulgaria, Georgia, Greece, Moldova, Romania, Russia, Turkey and Ukraine) signed the founding statement. The creation of the BSEC greatly contributed to forge greater interdependence among states in Europe and between Western states and the former communist Eastern countries, especially in the economic realm. Turkey's initiative proved to be a positive step for further development of multilateral cooperation in that area.

In June 2006, Romania launched the Black Sea Forum for Partnership and Dialogue (BLACKSEAFOR) and invited all the Black Sea states to take part. It is not a full-fledged regional organisation but mainly a regular consultative process, which should complement the other regional frameworks and contribute to enhancing mutual trust among the states. In 2005, Ukraine launched the Community of Democratic Choice, but this has been seen as a project to attract the US and EU into this area, consolidate the positions of Ukraine and Georgia and reduce Russian regional influence. This initiative remained isolated and did not really improve the regional level of cooperation, as Russia and Turkey were not at all enthusiastic about it. The BLACKSEAFOR is the most successful form of military cooperation in the WBSA. Turkey, Russia, Ukraine, Romania, Bulgaria and Georgia met in April 2001 at Istanbul to sign the document creating the Black Sea Naval Cooperation Task Group in order to contribute to the setting up of a secure environment in the Black Sea Area, ${ }^{66}$ thus enhancing mutual trust among the countries. BLACKSEAFOR activities are military cooperative exercises for enhancing naval security in the Black Sea without threatening other states. Emphasis was put on humanitarian needs, cleaning of sea mines and protecting the Black Sea environment.

\section{Conclusion}

In conclusion, the future of the Wider Black Sea Area depends on the developments of the strategic triangle Russia-Turkey-EU, and the Black Sea will probably be a testing space for relations between Russia and Turkey vs. the West. 
The US-Russia relations reset could also improve the prospects for the region but Barack Obama's decision to shift American strategic interests from Europe to the Asia-Pacific region suggests that Washington will not be a major player in the Wider Black Sea Area as it has been under the leadership of GW Bush. China could certainly play a more important role there; it has the necessary resources for projecting power but its areas of concern are now more to the east, in Asia. The US future anti-missile shield and its NATO complementary shield, which reached the interim capability at the NATO Chicago summit, suggest that the USA will continue to give strong security guarantees to the western Black Sea states. By doing this, the US will likely continue to antagonise Russia and China. The role of EU riparian states, Bulgaria and Romania, is also not negligible as they set up a role of regional stabiliser and provider of security. The main pillars for enhancing regional security are the CFE Treaty being accepted by NATO states and hopefully again by Russia, their desirable cooperation to the anti-missile shield, an accommodation between the EU and the future possible Eurasian Union, and the resolution of the "frozen conflicts" in a way that respects the territorial integrity of all the states. The enhanced economic cooperation and integration would also bring benefits.

\section{Endnotes}

${ }^{1}$ Ionescu, ME. "Securitate şi stabilitate în bazinul Mării Negre în epoca post război rece" (Security and stability in the Black Sea Area after the Cold War). In Ionescu, ME (ed.), Marea Neagră: De la lacul bizantin la provocările secolului $X X$ (The Black Sea: From the Byzantine lake to the $20^{\text {th }}$ century challenges). Bucharest: Editura Militară, 2006.

2 Dumitru, C \& Pavelescu, Ş. "Marea Neagră în timpul Războiului Rece, 19451990" (The Black Sea during the Cold War, 1945-1990). In Ionescu, Marea Neagră op. cit.

${ }^{3}$ For a definition and analysis of this region, see Asmus, R. "Developing a new Euro-Atlantic strategy for the Black Sea Region”. Istanbul Papers 2. 25-27 June 2004. Also Asmus, R \& Jackson, BP. "The Black Sea and the Frontiers of Freedom". Policyreview.

<http://www.policyreview.org/jun04/asmus.html > Accessed on 3 July 2011. The Wider Black Sea Area is a new American geopolitical concept, invented at the end of the nineties of the $20^{\text {th }}$ century, and which became notorious after the 11 September 2001 attacks on the World Trade Centre when the USA decided on a new geopolitical strategy to connect the Black Sea and Caucasus with the Greater Middle East as a belt of insecurity. 
${ }^{4}$ NATO. "Individual Partnership Action Plans".

<http://www.nato.int/issues/ipap/index.html > Accessed on 10 March 2010.

5 "At the 2008 Bucharest Summit we agreed that Georgia will become a member of NATO and we reaffirm all elements of that decision, as well as subsequent decisions." See the "Summit Declaration issued by the Heads of State and Government participating in the meeting of the North Atlantic Council in Chicago on 20 May 2012".

<http://www.nato.int/cps/en/natolive/official_texts_87593.htm?mode=pressr elease> Accessed on 23 March 2007.

${ }^{6}$ NATO. "The PfP Planning and Review Process (PARP)". 8 October 2002. <http://www.nato.int/docu/handbook/2001/hb030208.htm> Accessed on 15 March 2007.

7 "Crimea is against Sea Breeze”. RusNavy.com. 7 April 2010. <http://rusnavy.com/news/othernavies/index.php?ELEMENT_ID=9104> Accessed on 17 June 2010.

8“Russia ready for talks to extend Black Sea Fleet's stay in Crimea". RIA Novosti. 25 October 2006. See also Socor, V. "Putin offers Ukraine 'protection' for extending Russian Black Sea Fleet's presence”. Eurasian Daily Monitor X/200. 30 October 2006.

${ }^{9}$ Larrabee, SF. "NATO first? Why NATO has to lead a new Wider Black Sea strategy". Black Sea Paper Series 2. Washington, DC: German Marshall Fund of the United States. April 2008. 1-6.

10 "Address by the Minister of Foreign Affairs Radosław Sikorski". Ministry of Foreign Affairs, Poland. 19 November 2008.

<http://www.msz.gov.pl/index.php?document=23143> Accessed on 25 November 2008. See also Manea, O. "Calatorie prin universal Wikileaks" (A trip through the Wikileaks universe). Revista 22. 52. 21 December - 3 January 2011. 17.

${ }^{11}$ Niculescu, I. "Eagle Guardian planul de aparare al NATO in fata Rusiei" (Eagle Guardian, the NATO defense plan against Russia). Cotidianul. 7 December 2010.

${ }^{12}$ Legvold, R. "Russian foreign policy during periods of great state transformation". In Legvold, $\mathrm{R}$ (ed.), Russian foreign policy in the 21 century and the shadow of the past. New York: Columbia University Press, 2007, 77-144. See especially p. 130.

${ }^{13}$ Alexander Dugin, the right-wing leader of the International Eurasian Movement, is probably the most influential figure of geopolitician and pundit, his opinions being highly appreciated by Vladimir Putin. In his opinion, "[a] 
Eurasian Union will differ from the EU in that it will be based on Eurasian values, not European ones". "Russia: Putin advances Eurasian Union". Globalpost. 27 October 2011.

<http://www.globalpost.com/dispatch/news/regions/europe/russia/111026/ru

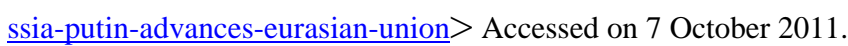

${ }^{14}$ Putin depicted the dissolution of USSR as "the biggest geopolitical catastrophe of the $20^{\text {th }}$ century”. See Carrère D'Encausse, H. URSS a murit, traiasca Rusia! (USSR is dead, long live Russia!). Bucharest: Artemis, 2010, 5-9.

${ }^{15}$ Pop, V. "Paris, US advisors back Russian veto over NATO enlargement". Euobserver.web. 17 March 2009. 〈http://euobserver.com/9/27789> Accessed on 25 April 2008.

${ }^{16}$ Bychenko, A. "Public opinion on NATO and Ukraine accession to it". National Security and Defense 9/81. 2006. 20.

${ }^{17}$ Cioculescu, SF. "Conflictele inghetate" (Frozen conflicts). In Ionescu, ME (ed.), Regiunea Extinsa a Marii Negre (The Wider Black Sea Area). Bucharest: Military Publishing House, 2009, 123-137.

${ }^{18}$ NATO. "The Bucharest Summit Declaration”. 3 April 2008. <http://www.nato.int/docu/pr/2008/p08-049e.html $>$ Accessed on 25 April 2008. The importance of the Black Sea was again underlined in the Chicago Summit Declaration of 20 May 2012.

${ }^{19}$ NATO. "Lisbon Summit Declaration". 20 November 2010. <http://www.nato.int/cps/en/natolive/official_texts_68828.htm?mode=pressr elease $>$ Accessed on 20 December 2010.

${ }^{20}$ I think Moscow would greatly prefer the former-Soviet territories to be unprotected as a way to have leverage during negotiations with Europeans and Americans.

${ }^{21}$ European Union. "EU and Russia launch new partnership for modernization". Europa. 1 June 2010.

<http://europa.eu/rapid/pressReleasesAction.do?reference=IP/10/649> Accessed on 7 September 2010.

22 "The Eastern Partnership is governed by the principles of shared ownership, differentiation and conditionality. Basing on Union values, standards and norms, it advances cooperation in such spheres as human rights, market economy, sustainable development, good governance, energy security and many others. The Eastern Partnership also stimulates and strengthens contacts between people and fosters scientific and cultural cooperation." "The Eastern Partnership". Ministry of Foreign Affairs of Poland. 1 October 
2012. <http://www.msz.gov.pl/Eastern,Partnership,19898.html > Accessed on 7 September 2010.

${ }^{23}$ European Union. "The Eastern Partnership”. Europa. 14 May 2009. <http://europa.eu/rapid/pressReleasesAction.do?reference=MEMO/08/762> Accessed on October 2, 2012.

${ }^{24}$ Paet, U. "Is the EU's Eastern Partnership initiative yielding results?" Europesworld. 20 May 2012. < http://www.europesworld.org/NewEnglish/Home old/PartnerPosts/tabid/6 71/PostID/2564/language/en-US/Default.aspx $>$ Accessed on 25 July 2012.

${ }^{25}$ Larrabee, SF. "NATO and Black Sea security". ISN. 30 May 2003. $<$ http://www.isn.ethz.ch/isn/Current-Affairs/ISNInsights/Detail?lng=en\&ots627=fce62fe0-528d-4884-9cdf283 c282cf0b2\&id=92478> Accessed on 10 September 2007. The author mentions that there are two main schools of thought: one who sees the EU as playing the biggest role in Central-Eastern Europe as provider of welfare and socio-economic security, the other emphasising the role of NATO as number one player. The adepts of the first scenario say that Russia is stronger today, the Black Sea states such as Georgia and Ukraine are weaker in security terms than the Balkan states, NATO is occupied in Afghanistan and the USA is strategically moving from Europe to the Middle East and especially to the Pacific and Asia.

${ }^{26}$ Russia also wants to buy VBL light amphibious armoured vehicles from the French Panhard General Defense Company. It also wants to modernise the engine of the Russian Ka-62 helicopter with the French Turbomeca.

${ }^{27}$ Socor, V. "Mistral case presages Russian shopping spree for Western military technology: Part two". Eurasia Daily Monitor 71. April 2010.

${ }^{28}$ Martin, LG \& Keridis, D. Turkey's Middle East foreign policy: The future of Turkish foreign policy. Cambridge: MIT Press, 2002.

${ }^{29}$ Torbakov, I. "The Turkish factor in the geopolitics of the post-Soviet space". IICAS. 23 December 2002. 〈http://iicas.org/2003en/08_01_03an_en.htm>

${ }^{30}$ Ibid. Accessed on 17 September 2003.

${ }^{31}$ Ionescu, ME. "The Black Sea in international relations: From the Crimean War to the end of the Second World War (1856-1947)". Paper delivered at the PfP Consortium of Defense Academies and Security Institute's SAC meeting, Rome, September 2005.

${ }^{32}$ Charap, S. "The Petersburg experience: Putin's political career and Russian foreign policy”. Problems of Post-Communism 51/1. 2004 
${ }^{33}$ Jackson, BP. "The archaeology of modern Europe”. Strategic Issues Review. Bucharest: NATO Studies Center, 2004.

${ }^{34}$ In fact, Russia signed the document in 1994 but then did not ratify it.

${ }^{35}$ Waltz, K. "The emerging structure of international politics". International Security 18/2. Fall 1998. 44-79. Mastanduno, M. "Preserving the unipolar movement”. International Security 21/4. Spring 1994. 54.

${ }^{36}$ Cioroianu, A. Geopolitica Matrioskai: Rusia postsovietica in noua ordine mondiala (The geopolitics of the Matrioska: Post-Soviet Russia in the new world order). Bucharest: Curtea Veche, 2009.

${ }^{37}$ Nikolai Berdiaev went much further in analysing Russian people's psychology and stated that " $[\mathrm{t}]$ he Russian people does not want to be a masculine builder, its nature defines itself as feminine, passive and submissive in matters of state, it always awaits a bridegroom, a man, a ruler. Russia ... is a land submissive and feminine. The passive, the receptive femininity in regard to the state power ... is so characteristic for both the Russian people and for Russian history". Berdiaev, N. The psychology of the Russian people: The soul of Russia. 1915.

<http://www.berdyaev.com/berdiaev/berd_lib/1915_007.html> Accessed on 4 March 2010.

${ }^{38}$ Kennan, G. "Long telegram”.22 February 1946. $<$ http://www.gwu.edu/ nsarchiv/coldwar/documents/episode1/kennan.htm.> Accessed on 12 May 2010. See also Kissinger, H. Diplomacy.New York: Simon and Schuster, 1994, 407.

${ }^{39}$ Tsygankov, A. Russia's foreign policy: Change and continuity in national identity. New York: Rowman \& Littlefield, 2010, 238.

${ }^{40}$ Cioculescu, SF. "Putting an end to the dialogue of the deaf between Romania and Russia? Struggling with the past, reshaping the future". Journal of East European and Asian Studies 1/3. May 2010. 320.

${ }^{41}$ Whitmore, B. "Sphere of reluctance: Russia hesitant about Kyrgyz intervention". Radio Free Europe. 15 June 2010.

${ }^{42}$ Kilner, J. "Uzbekistan withdraws from Russia-lead military alliance". Telegraph. 2 July 2012.

<http://www.telegraph.co.uk/news/worldnews/asia/uzbekistan/9369392/Uzb ekistan-withdraws-from-Russia-lead-military-alliance.html > Accessed on 4 August 2012.

${ }^{43}$ Weitz, R. "Eurasian security after Astana". Cacyanalist. 22 December 2010. <http://www.cacianalyst.org/?q=node/5467> Accessed on 6 January 2010 
44 "No need to rush US base withdrawal from Central Asia - CIS sec chief".

Armeniandiaspora. 27 July 2005.

$<$ http://www.armeniandiaspora.com/showthread.php?33473-No-need-torush-US-base-withdrawal-from-Central-Asia-CIS-sec-chief $>$ Accessed on 6 August 2005.

${ }^{45}$ Shustov, A. "More US-NATO military bases: US Armed Forces in Central Asia built to last". Global research. 17 August 2010.

<http://www.globalresearch.ca/index.php?context=va\&aid=20668>

Accessed on 28 August 2010.

${ }^{46}$ Wine trade with Russia is responsible for $80-90 \%$ of the total wine exports in both countries. "Russian wine move draws protests". BBC. 30 March 2006. <http://news.bbc.co.uk/2/hi/europe/4860454.stm> Accessed on 1 April 2006.

${ }^{47}$ Socor, V. "Conflictele înghețate: o provocare pentru interesele euroatlantice" (Frozen conflicts: A challenge for Euro-Atlantic interests). In Asmus, R, Dimitrov, K \& Forbrig, J (eds), O nouă strategie euro-atlantică pentru regiunea Mării Negre (A new Euro-Atlantic strategy for the Black Sea Region). Bucharest: German Marshall Fund, Institutul Român de Studii Internaționale, 2004, 127-138.

${ }^{48}$ Tymoshenko, Y. "Containing Russia". Foreign Affairs 86/3. May/June 2007. 6982.

${ }^{49}$ Some argue that in fact Georgia was the aggressor in August 2008, but according to international law, Georgia as a sovereign state had the right to intervene on its secessionist areas to impose the respect of the law and defend its territorial integrity. Anyway, Georgia made the mistake to use violent means instead of continuing to use peaceful means of settling its 'frozen conflicts' in South Ossetia and Abkhazia.

${ }^{50}$ See the war's interpretation by some security experts: King, C. "The Five-Day War". Foreign Affairs. November-December 2008 and Allison, R. "Russia resurgent? Moscow's campaign to coerce Georgia to peace". International Affairs 84/6. 2008. 1145-1171.

${ }^{51}$ Voronov, V. "Pocemu Gruzinskie Voiska Stoli Bistro Vyshli iz Boya?" Novoe Vremya 34. 25 August 2008.

<http://newtimes.ru/magazine/2008/issue080/doc-57257.html> Accessed on 10 July 2008; Nikolski, A. "Voina Menyaet Tehniku" Vedomoisti. 12 September 2008.

${ }^{52}$ Secrieru, S. "Russia after the South Caucasus Battle". CEPS Working Document 311. February 2009. 2-3. 
53 Arel, D. "Ukraine since the war in Georgia". Survival 50/6. December 2008 January 2009. 15-25. See specially p. 16. In fact, the president of Ukraine ordered that the Russian warships, warplanes, submarines should give 72 hours' notice before moving within Ukrainian territory or risk consequences.

${ }^{54}$ Korduban, P. "Kyiv on Georgia: Diplomacy awkward, parties divided". Eurasia Daily Monitor 5/157. 15 August 2008.

${ }^{55}$ Pifer, S. "Missile defense in Europe: Cooperation or contention?" Brookings. May 2012. <http://www.brookings.edu/research/reports/2012/05/08-missiledefense-pifer> Accessed on 6 July 2012

${ }^{56}$ Richard, W. "Eurasian security after Astana". Cacianalyst. 22 December 2010. <http://www.cacianalyst.org/?q=node/5467> Accessed on 17 January 2011.

57 “The Draft of the European Security Treaty”. Kremlin. 29 November 2009. <http://eng.kremlin.ru/news/275> Accessed on 10 October 2012.

${ }^{58}$ Ibid.

${ }^{59}$ Allison, R. "The unresolved conflicts in the Black Sea Region". In Pavliuk, O \& Klimpush-Tsintadze, I (eds), The Black Sea Region: Cooperation and security building. Bucharest: East West Institute, 2004, 86-122.

${ }^{60}$ Socor, "Conflictele înghețate ...", op. cit., pp. 127-138. See also Allison "The unresolved conflicts ... op. cit., p. 87.

${ }^{61}$ Roper, S. "From frozen conflict to frozen agreement". In Bahcheli, T, Bartmann, B \& Srebrnik, H (eds), De facto states: The quest for sovereignty. London: Routledge, 2004, 102-117.

${ }^{62}$ Lavrov, S. "Russia and the world in the $21^{\text {st }}$ century". Russia in Global Affairs 3. July-September 2008.

${ }^{63}$ Sharip, F. “Astana OSCE Summit ends in division”. Eurasia Daily Monitor 7/223. 14 December 2010.

${ }^{64}$ NTI. "CFE Treaty". $\langle$ http://www.nti.org/e research/official docs/inventory/pdfs/cfe.pdf $>$ Accessed on 21 December 2010.

${ }^{65}$ GUAM (GUUAM) was named after the initial letters of each of member countries, thus after the retreat of Uzbekistan it became GUAM.

${ }^{66}$ Asmus op. cit. Also Asmus \& Jackson op. cit. <http://www.policyreview.org/jun04/asmus.html> Accessed on 25 July 2004. The Greater Black Sea Area is a geopolitical concept and comprises the riparian states and also those who are connected within the same security complex: Azerbaijan, Armenia and Moldova. 